\section{DE DE GRUYTER} OPEN
Journal of Intercultural Management

Vol. 6, No. 3, September 2014, pp. 167-176

DOI 10.2478/joim-2014-0027

Piotr Masiukiewicz*

Warsaw School of Economics

\title{
Multicultural issues in the development of Islamic banking
}

\begin{abstract}
Islamic banking is highly specific and is based on the Sharia law. This banking offers new products. which comply with the prohibitions of riba, maysir, gharar. Dynamic development of this banking in the word is the consequence of its opening to culturally diverse clients, and not only Muslims. Numerous researches demonstrate that many not-Muslim clients use the financial products which are offered in Islamic banks and in the "Islamic windows" in conventional banks. The Islamic banking offer is increasingly more often dedicated to the clients beyond the Muslim community, and at the same time the products dedicated to this community are offered by traditional banks. In this way the Islamic banking offer diffuses to other cultures.
\end{abstract}

Key words: conventional banks, financial product, Islamic banking, multiculturalism, Sharia.

\section{Introduction}

Failure of assimilation ideologies contributed to the emergence of numerous studies and publications on multiculturalism [Śiz A., Szczepański M. S., 2011]. This issue is also important in banking, and not only due to the globalization processes, but also owing to the emergence of the alternate Islamic banking.

Islamic financial sector consists of 600 bank institutions and over 700 investment funds with more than 2 trillion dollars in assets. Islamic banking navigated through the international subprime crisis without any significant losses. The global dynamics of growth in this sector are impressive. In recent years, Islamic banking saw increase in assets ranging from 15 to $20 \%$ per annum. Growth of Islamic banking is a result of, among others, conservative ethics and its openness to culturally diverse clients, not only Muslims. Researches demonstrate that many non-Muslims use products offered by Islamic banks and 'Islamic windows' in conventional banks.

* piotr.masiukiewicz@wp.pl 
Therefore Islamic banking offer is addressed to customers beyond Muslim communities, and at the same time Muslim financial products are being offered by global, conventional banks. [Solé J., 2007] Is this a permanent process? Can Islamic banking flourish in other cultures? What are the obstacles to these processes? This articles attempts to answer these questions.

Islamic banking has its peculiarities. It is based on the Sharia law (also referred to as Islamic law). This means that the clients must accept certain specific financial products that are based on the Sharia law, given they want to use these products. [Ayub M., 2007]

Multiculturalism in banking can be analyzed in the following areas:

- availability of global banks' offer to the clients from various geographies and cultures

- cultural diversity of the staff in global banks,

- mixing of financial products and clients of conventional and Islamic banking.

This article aims to investigate the latter area.

Islamic banking is not a new topic in Polish economic literature, but its focus on the Islamic finance may lead to misinterpretations. This is particularly true with regard to the religious dimension, historical context or its socio-political role in Muslim countries.

This artice employs the following research methods: literature analysis, desk research and statistical analysis.

\section{The Sharia law and peculiarities of Islamic financial products}

Sharia law has no equivalent in Western concepts of law, and thus is often misinterpreted. Sharia should not be compared neither to statutory laws nor to canonical laws. Statutory law has been developed by men and is subject to change, while Islamic law has been revealed by God, and therefore cannot be changed by a man. Canonical law, in turn, relates only to religious matters, while sharia governs all aspects of private and social life of a Muslim.

In Arab countries there is a distinction between the law in the Western sense of the word (which is called 'kanun') and Islamic law. [Dziekan M., 2003]

Sharia law constitutes economic activities in Islamic countries. [Górak-Sosnowska K., Masiukiewicz P., 2013] It governs economic and financial relations and is a religious law based on Quran. Compliance with these regulations relates primarily to economic relations between economic entities and households that comply with Islamic principles. In economic relations with people of other religions, certain derogations from the principles of Sharia law are allowed.

There are three fundamental prohibitions under the Sharia law. [Zachodnie banki...,2014] The first is ban on Riba, i.e. interest prohibition. Islamic law also imposes prohibition of Gharar, i.e. prohibition of risky or hazardous transactions, 
where details concerning the sale item are unknown or uncertain, e.g. derivatives. The third prohibition is prohibition of Maysir, i.e. prohibition of engaging in any unethical transactions such transactions related to alcohol, drugs, gambling, pork trade and etc. [Górak-Sosnowska K., Masiukiewicz P., 2013, p. 38 and next] Another principle governing economic relations in Muslim countries is the warrant of Zakat (obligation to give alms/donations) and the principle of Darar, defining a framework for the protection of third parties that may suffer the consequences of other economic transactions.

Sharia law restrictions prevent the use of derivatives (futures). It is believed that it was one of the reasons why the Islamic banking sector did not suffer from the financial subprime crisis, as well as from the earlier crises.

Legal-religious legislation is largely based on the interpretations issued by experts (with permits) in the form of fatwas and by the Sharia boards. Sharia councils exist at banks, investment funds and other institutions. In addition to sharia law, Muslim countries also have statutory laws - civic law, foreign exchange law or financial law. [Górak-Sosnowska K., 2007]

In the absence of interest-based loans, Islamic banks and investment funds provide enterprise financing under the profit-and-loss sharing principle (PLS). The concept of PLS is based on the idea of the borrower's and the bank's participation in the enterprise's profits or losses in a prefixed rate documented earlier in the agreement.

In Islamic banking sector, the provisions of Islamic law are interpreted by Sharia boards which are appointed at all banks. [Iqbal M., Molyneux P., 2005, p. 114] These boards oversee the compliance of the bank's products with the restrictions of the Sharia law, and issue certificates of compliance. In other words, Sharia councils ensure that Islamic banks are 'truly Islamic'. In practice, this may lead to the subordination of the economic interest to religious principles. This is particularly true in certain banks where Sharia Boards have the authority to issue fatwas contradicting decisions made by the bank's board. In addition, one member of the Sharia Board is often appointed to the board (and vice-versa - one of the bank's board members may be appointed to the Sharia Board). [Abdul-Rahman Y., 2010, p. 77]

\section{Islamic offer in light of research}

The dynamic of Islamic banks' recent growth is highly desirable. The global value of assets of Islamic banking in the last six years is shown on Graph 1. 
Figure 1. Global value of assets of Islamic banking (bln USD)

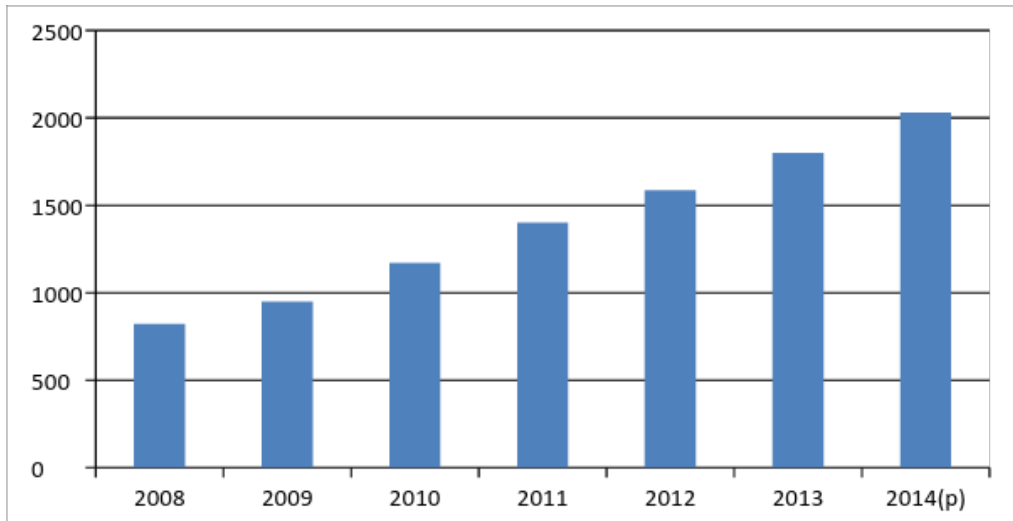

Notice: $\mathrm{p}$ - anticipation value

Source: own prepare in ground: [Ernst \& Young, 2013a, Ernst \& Young, 2013b]

Arguably, the subprime crisis enabled the new opening of Islamic banking to the global market. In principle, Islamic banking did not suffer from the crisis. [Recession Opens..., 2009] Moreover, it never experienced crises or bankruptcies before. Hence, conventional banks 'Islamic offer' is constantly expanding; as evidenced by the increase in the number of Islamic windows (see table 1) in those banks.

Islamic banks offer variety of products: current accounts, saving accounts, enterprise financing (these are specific products which are substitutes for loans) and capital market products (equities, Sukuk certificates, investment funds - listed on Islamic stock exchanges).

Table 1. Number of conventional banks which have Islamic windows

\begin{tabular}{|c|l|l|l|l|l|l|l|}
\hline \multicolumn{1}{|c|}{ Years } & \multicolumn{1}{|c|}{2007} & \multicolumn{1}{c|}{2008} & $\mathbf{2 0 0 9}$ & $\mathbf{2 0 1 0}$ & $\mathbf{2 0 1 1}$ & $\mathbf{2 0 1 2}$ & $\begin{array}{c}\text { Dynamic } \\
\mathbf{( \% )}\end{array}$ \\
\hline $\begin{array}{l}\text { Number of } \\
\text { banks }\end{array}$ & 163 & 194 & 192 & 199 & 205 & 206 & 126.4 \\
\hline
\end{tabular}

Source: [DiVanna, 2014]

For example, a study conducted in banks in Singapore indicated diverse origins of Islamic banks (by country of origin of capital) and diversified customer structure - using different distribution channels. This banking clearly bears the features of multiculturalism (table 2).

Citi Islamic Investment Bank, operating in Arab countries, is a good example of a bank offering Islamic financial products for both Islamic and non-Islamic cus- 
tomers. CIIB offers all products available in the Islamic financial sector (e.g. Mudharabah, Murabaha, Musharaka, Ijara, Salam). Due to its high activity, even among non-Muslim customers, the bank was able to increase revenues four times reaching profits of approx. USD 40,000 per year. The prime source of the CIIB's good results was its focus on the Murabaha products. The value of Murabaha transactions in the Middle East, in which the CIIB was involved, reached over USD 200million per year. [Górak-Sosnowska K., Masiukiewicz P., 2013, p. 174 and next]

Table 2. Origin of financial institutions and distribution channels of Islamic products in Singapore

\begin{tabular}{|l|l|l|}
\hline I. & Origin of financial institutions & Share $\%$ \\
\hline 1 & Europe & 36.4 \\
2 & South-Easter Asia & 27.2 \\
3 & East Asia & 18.2 \\
4 & West Asia & 18.2 \\
\hline II. & Distribution channels of Islamic products & Share $\%$ \\
\hline 1 & Islamic bank & 18.2 \\
2 & Islamic window in conventional bank & 54.6 \\
3 & Bank subsidiary (Islamic) & 27.2 \\
\hline
\end{tabular}

Source: [Górak-Sosnowska K., Masiukiewicz P., 2013, p. 158 and next]

Muslims (and non-Muslims) may receive credit cards and buy life or property insurance. They can also invest on-line in Islamic Investment Funds, and obtain mortgage from an American company that complies with the Sharia law. [Zachodnie banki a szariat, 2014]

Number of other global conventional banks, including Credit Agricole, Deutsche Bank, HSBC, Royal Bank of Scotland, Societe Generale, UBS, followed Citi Islamic Investment Bank.

Sukuk issues is one of the fields with further opportunities for development. These securities are primarily offered to Islamic buyers and may be used by conventional banks to finance large investments. For example, Volaw Trust Company (Jersey Island) received Jersey Financial Services Commission's approval for USD 26 millions Sukuk issue. International Innovative Technologies (manufacturer of industrial milling machines) was the first British company to issue Islamic Sukuk certificates in 2010 in order to raise equity for development investments. These securities were bought for USD 10 millions by Islamic private equity fund in the United Arab Emirates. 
Table 3. Clients motivations for use Islamic services and products. Answers in \%

\begin{tabular}{|c|c|c|c|c|c|}
\hline Contents & $\begin{array}{l}\text { Strongly } \\
\text { agree }\end{array}$ & Agree & No opinion & Disagree & $\begin{array}{l}\text { Strongly } \\
\text { disagree }\end{array}$ \\
\hline 1.Religious motivation & 71.6 & 22.3 & 2.5 & 1.5 & 0.0 \\
\hline 2.Economic factors & 4.8 & 10.7 & 22.8 & 30.6 & 28.8 \\
\hline 3.Religious and eco- & & & & & \\
\hline nomic factors & 12.9 & 24.0 & 28.2 & 21.2 & 8.7 \\
\hline 4.Family suggestions & 12,7 & 26.5 & 25.3 & 24.0 & 8.5 \\
\hline 5.Friends' suggestions & 24.2 & 12.3 & 28.3 & 21.7 & 7.9 \\
\hline 6. Bank localization & 17.3 & 35.3 & 21.7 & 11.3 & 5.7 \\
\hline $\begin{array}{l}\text { 7.Low banking provi- } \\
\text { sion }\end{array}$ & 9.3 & 34.6 & 28.3 & 13.5 & 5.5 \\
\hline $\begin{array}{l}\text { 8.Bank effectivity in } \\
\text { realized transaction }\end{array}$ & 4.7 & 41.3 & 31.5 & 14.6 & 3.1 \\
\hline 9.Palette of approach- & 7.5 & 35.7 & 41.3 & 5.3 & 7.7 \\
\hline $\begin{array}{l}\text { able of products and } \\
\text { services }\end{array}$ & 0.0 & 29.7 & 53.1 & 11.5 & 5.2 \\
\hline $\begin{array}{l}\text { 10.Services quality } \\
\text { 11. Banks reputation and }\end{array}$ & 19.6 & 49.3 & 17.3 & 4.6 & 1.7 \\
\hline $\begin{array}{l}\text { image } \\
\text { 12.Exist sharia board } \\
\text { in bank }\end{array}$ & 23.2 & 34.3 & 24.8 & 3.5 & 1.5 \\
\hline $\begin{array}{l}\text { 13. Islamic bank have } \\
\text { similary offer as con- } \\
\text { ven-tional bank, bud } \\
\text { products comply with } \\
\text { Islam }\end{array}$ & 22.3 & 32.7 & 29.2 & 0.0 & 1.5 \\
\hline
\end{tabular}

Source: [Aashir M., 2012, p. 36]

The question arises, what criteria do the customers of Islamic banks employ, both followers and non-followers of Islam, when deciding to use the offer. Contrary to appearances, religious motifs are important but not the only one. Twenty two percent of respondents said that an important motivation is that Islamic banks offer similar products to those of conventional banks. Family and friends' suggestions were also indicated as important by a significant portion of the participants, similarly to the bank's location. Finally, low banking provisions were also vital for the customers of Islamic banks (table 3).

Customer satisfaction surveys are extremely rare in Islamic banking. Results from a study on customer satisfaction in Malaysia are presented in table 4. Customers of Islamic banks' branches in Malaysia were moderately satisfied with the quality of the services provided by the banks.

The highest level of dissatisfaction was noted in the area of response time and reliability of service. Information about time required to provide a service, individual attitude towards customer, and understanding of individual needs by the bank's employee and modern equipment were all rated unsatisfactory (table 4). 
Table 4. Clients satisfaction in Islamic banks in Malaysia

\begin{tabular}{|l|l|l|l|l|}
\hline \multicolumn{1}{|c|}{ Area } & Expectations & \multicolumn{1}{c|}{ Perceptivity } & \multicolumn{1}{c|}{ Gap1 } & Position \\
\hline According with principles & 4.47 & 4.14 & -0.33 & 6 \\
\hline Certainty of safety & 4.28 & 3.92 & -0.36 & 5 \\
\hline Tangibility & 4.24 & 3.84 & -0.4 & 3 \\
\hline Emphatia & 4.05 & 3.66 & -0.39 & 4 \\
\hline Reliability & 4.18 & 3.76 & -0.42 & 2 \\
\hline Response time & 4.2 & 3.75 & -0.45 & 1 \\
\hline Average & 4.24 & 3.84 & -0.4 & x \\
\hline
\end{tabular}

Notice: 1 . Gap = index of perceptivity - index of expectations

Source: [Tahir I.M., Abu Bakr N.M., Wan Ismail W.Z., 2008, p. 13]

These issues are addressed through new customer service technologies and distribution channels such as mobile banking and post offices increasingly often. [Tahir I.M., Abu Bakr N.M., Wan Ismail W.Z., 2008, p. 12, Solé J., 2007]

\section{Perspectives for growth}

In highly-developed, non-Muslim countries migration of Muslim population will create demand for financial services based on sharia law, and for Sukuk certificates [Masiukiewicz P. 2013c].

A significant demand for Muslim financial products may also occur in thirdworld countries, with a significant share of poor population. We can already observe a rapid development of so-called Muslim microfinance in such countries [Adamek J., 2010].

The current dynamics of the Islamic banking development can be maintained if it continues to be open to customers of other religions who accept Islamic financial products and will sell the products through Islamic windows in conventional banks.

United Kingdom is a good example of the rapid expansion of Islamic banking. In addition to Islamic windows in conventional banks, there are five Islamic banks in the UK [Górak-Sosnowska K., Masiukiewicz P., 2013, p. 97].

Growth of Islamic banking in non-Muslim countries (including Central and Eastern Europe, e.g. Poland) would require new, special regulations to be incorporated into the banking law. Regulatory changes adjusting banking regulations were recently implemented, among others, in France. Lack of relevant changes in Russia led to closure of Badr Bank, a large Islamic bank.

Investors' interest in financing domestic and international investments via Islamic Sukuk certificates will likely remain stable with regard to large infrastructure investments.

As regards Central and European countries, Islamic banks may become important centers of financing and accounting trade transactions. 
Many Muslim countries are home to sovereign (investment) wealth funds. [Górak-Sosnowska K., Masiukiewicz P., 2013, p. 195] Their aim is to invest in high yielding ventures around the world. These funds invested approximately $40 \%$ of their assets in Europe (table 5). Poland, having good economic and political relations with most Muslim countries, could benefit from these measures.

Table 5. Sovereign wealth funds in Muslim countries

\begin{tabular}{|l|l|l|l|l|}
\hline No. & \multicolumn{1}{|c|}{ Country } & \multicolumn{1}{|c|}{ Fund name } & $\begin{array}{c}\text { Assets under } \\
\text { management } \\
\text { (USD bn) }\end{array}$ & \multicolumn{1}{|c|}{$\begin{array}{c}\text { Date of estab- } \\
\text { lishment }\end{array}$} \\
\hline 1 & Azerbaijan & State Oil Fund of Azerbaijan & 1,5 & 1999 \\
\hline 2 & Bahrain & Mumtalakat Holding Company & 10.0 & 2006 \\
\hline 3 & Kuwait & Kuwait Investment Authority & 169.0 & 1953 \\
\hline 4 & Libya & Libyan Investment Authority & 65.0 & 2006 \\
\hline 5 & Malaysia & Khazanah Nasional Bhd & 23.1 & 1993 \\
\hline 6 & Oman & State General Reserve Fund & 8.2 & 1980 \\
\hline 7 & Qatar & Qatar Investment Authority & 58.0 & 2005 \\
\hline 8 & UAE & Emirates Investment Authority & 20.0 & 2007 \\
\hline 9 & UAE /Abu Zabi & Abu Dhabi Investment Authority & 282.0 & 1976 \\
\hline 10 & UAE/Abu Zabi & Abu Dhabi Investment Council & $\mathrm{n} / \mathrm{d}$ & 2006 \\
\hline 11 & UAE/Abu Zabi & Mubadala Development Company & 14.7 & 2002 \\
\hline 12 & UAE /Dubai & DIFC Investment Co. LLC & $\mathrm{n} / \mathrm{d}$ & 2006 \\
\hline 13 & UAE / Dubai & Investment Corporation of Dubai & 82.0 & 2006 \\
\hline 14 & UAE / Dubai & Istihmar World & 9.0 & 2003 \\
\hline 15 & UAE / Ras al- & RAK Investment Authority & 1.2 & 2005 \\
\hline
\end{tabular}

Source: [Miracky W. Bortolotti B., 2009]

Obstacles to growth for Islamic banking include insufficient investments in branch network, incompatibility of significant share of ATMs with international debit and credit cards, poorly developed loan market and low marketing expenditures.

Further growth of Islamic banking also depends on the harmonization of Islamic banking regulations on the global scale. [Masiukiewicz P., 2013b] Accounting and Auditing Organization for Islamic Financial Institutions is working on these issues for many years.

\section{Conclusions}

Islamic banking product range can be currently found in both Islamic and conventional banks. Conventional banks offer Islamic products increasingly often. It is reasonable to suppose that the trend of growth of Islamic banking will continue. Support from international organizations representing Islamic banking industry 
(including Islamic Financial Services Board) and promotion of its openness to culturally diverse customers will be favorable for the international expansion of Islamic financial institutions.

In the financial banking we could clearly observe two trends: transmission of Sharia-based Islamic banking products into conventional banking, and float of nonMuslim clients (both retail and corporate) towards the Islamic financial system.

It can be assumed that other European financial institutions will introduce 'Islamic windows' together with Islamic securities to their offer, and that it will happen in the near future. It is also reasonable to expect that the ,multicultural factor' will remain present in the new perspective of Islamic banking.

\section{Bibliography}

Aashir, M. (2012), Customer Satisfaction in Islamic Banking in Pakistan, Lambert, Saarbrucken.

Abdul-Rahman, Y., (2010) The art of Islamic Banking and Finance, John Wiley \& Sons.

Adamek, J. (2010), Mikrofinanse islamskie, Wydawnictwo CeDeWu.pl, Warszawa.

Ayub, M., (2007), Understanding Islamic Finance, John Wiley and Sons.

5. DiVanna, (2014) J., Islamic Finance Industry Reaches Critical Mass, The Banker, November 7, http://www.thebanker.com/Reports/Special-Reports/Top-Islamic-financial-institutions/ Islamic-finance-industry-reaches-critical-mass, access: 23.07.2014.

Dziekan M., (2003), Prawo muzutmańskie wczoraj i dziś, in: Oblicza wspótczesnego islamu, E. Machut-Mendecka (ed.), Academica, Warszawa.

Ernst \& Young, (2013a), World Islamic Banking Competitiveness Report 2012-2013, Ernst \& Young, Dubaj, 2013.

Ernst \& Young, (2013b), World Islamic Banking Competitiveness Report 2013-14, The Transition Begins, Ernst \& Young, Dubaj.

Górak-Sosnowska, K. (2007), Świat arabski wobec globalizacji. Uwarunkowania gospodarcze, kulturowe i spoteczne, Difin, Warszawa.

Górak-Sosnowska, K., Masiukiewicz, P. (2013), Bankowość muzutmańska, Oficyna Wydawnicza SGH, Warszawa.

Hassan, M., Dridi, J., (2010), The Effects of the Global Crisis on Islamic and Conventional Banks: A Comparative Study, IMF Working Paper no. WP/10/2010, Washington.

Iqbal, M., Molyneux, P., (2005), Thirty Years of Islamic Banking. History, Performance and Prospects, Palgrave Macmillan, New York.

Kahf, M., Ahmad, A., Homud, S., (1998), Islamic Banking and Development an Alternative Banking Concept?, IRTI.

Masiukiewicz, P. (2013a), Bankowość muzutmańska - trzeci megasektor, Instytut Zarządzania Wartością SGH, www.ValueComesFirst.pl Warszawa, access 11.07.13

Masiukiewicz, P. (2013b), Ryzyko w bankowości muzutmañskiej, Bank no. 10.

Masiukiewicz P. (2013c), Murutmańskie certyfikaty sukuk, www.aleBank.pl access 15.10.2013 
Miracky, W. Bortolotti, B. (2009), Weathering the Storm. Sovereign Wealth Funds in the Global Economic Crisis of 2008, SWF Annual Report 2008, Monitor Group, April.

Paxford, B., (2010), cQuestions of Price and Ethics: Islamic Banking and its Competitiveness, New Horizon.

'Recession Opens Door for Islamic Finance', (2009), International Tax Review, July/August

Solé, J., (2007), Introducing Islamic Banks into Conventional Banking Systems, IMF, Washington, July.

Śiz, A., Szczepański, M. S. (2011), 'Wielokulturowość i jej socjologiczny sens. Festival caravan czy wielokulturowe street party?' Studia Socjologiczne no. 4.

Tahir, I.M., Abu Bakr, N.M., Wan Ismail, W.Z., (2008), 'Customer Expectations and Perceptions of Service Quality in Islamic Banking. Evidence from Malaysia’, Journal of Islamic Economics, Banking and Finance.

Trzaskowska-Dmoch, A. (2014), Różnorodność społeçna i kulturowa crynnikiem wplywu warunkujacym stopień integracji europejskiej, w: Perspektywy i wyzwania integracji europejskiej, red. K. Opolski, J. Górski, Wydział Nauk Ekonomicznych Uniwersytetu Warszawskiego, Warszawa.

Zachodnie banki a szariat, (2014) http://www.ipdirect.home.pl/kmp/zachodniebanki_a_ szariat.htm, access 15.02 .14 